\title{
Efektifitas Load Balancing Dalam Mengatasi Kemacetan Lalu Lintas
}

\author{
Erwin Harahap ${ }^{1}$, Andri Suryadi ${ }^{2}$, Ridwan ${ }^{3}$, Deni Darmawan ${ }^{4}$, Rakhmat Ceha ${ }^{5}$ \\ ${ }^{1}$ Program Studi Matematika, FMIPA, Universitas Islam Bandung \\ ${ }^{2}$ Program Studi Pendidikan Teknologi Informasi, Institut Pendidikan Indonesia Garut \\ ${ }^{3}$ Program Studi Perencanaan Wilayah Kota, Institut Teknologi Bandung \\ ${ }^{1}$ Program Studi Teknologi Pendidikan, Universitas Pendidikan Indonesia. \\ ${ }^{5}$ Program Studi Teknik Industri, Universitas Islam Bandung. \\ erwin2h@unisba.ac.id, andrisuryadi@institutpendidikan.ac.id, ridwan@itb.ac.id, \\ d_darmawan@upi.edu, rceha@unisba.ac.id
}

\begin{abstract}
Abstrak. Kemacetan jalan raya merupakan permasalahan umum di setiap kota yang memerlukan penanganan serius. Pemecahan permasalahan kemacetan jalan raya tidak hanya dapat diselesaikan dengan hanya meningkatkan kualitas dan kuantitas infrastruktur, namun juga manajemen lalu lintas. Pada artikel diusulkan suatu metode untuk mengurangi kemacetan lalu lintas, yaitu dengan menyeimbangkan beban ke berbagai ruas jalan yang disebut dengan load balancing. Melalui metode ini diharapkan beban lalu lintas terbagi secara merata ke berbagai jalur alternatif sedemikian sehingga antrian panjang kendaraan dapat dihindari. Evaluasi efektifitas dari metode load balancing ini dilakukan melalui simulasi dengan mengimplementasikan salah satu bidang ilmu Matematika, yaitu teori Antrian. Simulasi dibuat dengan menggunakan toolbox SimEvents yang dijalankan pada software MATLAB.
\end{abstract}

Kata Kunci: load balancing, kemacetan, lalu lintas, sim-events, matlab

\begin{abstract}
Road congestion is a common problem in any city that needs serious handling. The solution of the road congestion problems can not only be solved by simply improving the quality and quantity of infrastructure, but also the traffic management. In this article, we proposed a method to reduce the traffic congestion by balancing the vehicle loads to a various road segments, called as load balancing. Through this method, it is expected that the traffic load is evenly distributed to various alternative routes, such that, long queues and traffic jam can be avoided. Evaluation of the load balancing's effectiveness is performed through a simulation by implementing the Queueing Theory. Simulations are created using the SimEvents toolbox that runs on MATLAB software.
\end{abstract}

Keywords: load balancing, road congestion, traffic, simevents, matlab.

\section{Pendahuluan}

Kemacetan terjadi disebabkan oleh panjangnya antrian kendaraan karena terhambatnya arus lalu lintas karena dua faktor: terbatasnya kapasitas jalan atau jumlah kendaraan yang terlalu banyak [1]. Solusi sederhana untuk pemecahan masalah kemacetan ini adalah dengan meningkatkan kapasitas jalan dan mengurangi jumlah kendaraan [2]. Namun pada pelaksanaannya, solusi tersebut tidaklah sederhana. Peningkatan kapasitas jalan membutuhkan biaya yang sangat besar, disamping proses pembebasan lahan yang harus melalui sangat rumit dan berlarut-larut. Mengurangi jumlah kendaraan juga tidak mudah, karena terkait dengan kebijakan pemerintah [3], dan juga ketergantungan 
masyarakat terhadap sarana transportasi yang sudah menjadi kebutuhan utama dan tidak bisa dilepaskan dalam aktifitas rutin [4].

Kemacetan umumnya terjadi di kota-kota besar yang memiliki manajemen lalu lintas yang tidak begitu baik. Kemacetan juga terjadi karena adanya ketimpangan antara jumlah kendaraan dengan kapasitas jalan. Kota yang memiliki jumlah penduduk yang sangat padat, misalnya Jakarta Bandung, Surabaya, Semarang, Medan, dan beberapa kota lainnya di Indonesia, sangat rawan terjadi kemacetan di beberapa titik yang beririsan dengan lokasi publik seperti Pasar, Sekolah, Terminal Bus, dan lain lokasi serupa lainnya. Kemacetan juga dapat terjadi pada perpotongan jalur lalu lintas seperti di persimpangan lampu merah atau persimpangan rel kereta api. Kemacetan lalu lintas dapat juga terjadi karena disebabkan oleh adanya kecelakaan, bencana alam (misalnya banjir, tanah longsor, kebakaran di jalan, kebakaran di pemukiman, dll). [5]

Kemacetan jalan raya sangat penting untuk diatasi permasalahannya karena sangat merugikan dan memberikan dampak negatif yang besar terhadap aktifitas kehidupan masyarakat luas. Diantaranya adalah kerugian waktu karena perjalanan transportasi terhambat, pemborosan energi/bahan bakar, kendaraan lebih cepat rusak karena panas mesin yang berlebihan, meningkatnya polusi udara, seringkali kemacetan meningkatkan stress dan emosional para pengguna jalan. Dampak negatif kemacetan adalah mengganggu kelancaran transportasi darurat seperti ambulans dan pemadam kebakaran.

Pada artikel ini, kami mengajukan sebuah penelitian untuk mengatasi permasalahan kemacetan jalan raya melalui sisi manajemen lalu lintas, yaitu dengan metode mengarahkan kendaraan secara merata/seimbang (balance) pada beberapa jalur alternatif. Metode pengalihan kendaraan secara seimbang ini kami namakan sebagai metode "Load Balancing". Melalui metode ini diharapkan terjadi pemerataan beban lalu lintas, sehingga kemacetan dapat dihindari.

Selengkapnya isi dari artikel ini adalah sebagai berikut: Pada sub-bab kedua, dibahas mengenai latar belakang dan motivasi dari usulan metode load balancing. Sub-bab ketiga berisi mengenai metodologi load balancing beserta beberapa parameter yang butuhkan untuk simulasi lalu lintas dengan mengimplementasikan usulan pemecahan masalah. Sub-bab keempat berisi mengenai implementasi dari simulasi berdasarkan pada data lalu lintas, sekaligus berisi diskusi mengenai hasil dari simulasi. Sub-bab terakhir berisi kesimpulan beserta saran untuk pengembangan penelitian terkait.

\section{Latar Belakang dan Motivasi}

Kemacetan sudah menjadi masalah umum dan telah dilakukan banyak cara untuk menemukan solusinya. Beberapa solusi pemecahan masalah kemacetan telah diusulkan oleh beberapa lembaga dan juga para peneliti. Diantaranya adalah dengan memperlebar jalan, menambah lajur lalu lintas, rekayasa sirkulasi lalu lintas satu arah, pembatasan melalui median jalan atau barikade yang membatasi arus belok, membangun fly-over, pengembangan manajemen jalan melalui intelligent transportation sistem, pemberian sangsi terhadap para pelanggar, dan lain sebagainya. Namun dikarenakan kemacetan adalah masalah yang sangat kompleks, sehingga walaupun beberapa solusi telah diimplementasikan, namun kemacetan tetap terjadi.

Pada artikel ini, penulis memfokuskan diri pada satu kota untuk ditelaah mengenai situasi kemacetan yang terjadi, yaitu kota Bandung. Beberapa alternatif solusi untuk mengatasi kemacetan telah dilakukan, baik berupa peningkatan infrastruktur maupun manajemen berupa berbagai rekayasa lalu lintas. Namun satu hal belum diimplementasikan, yaitu pembagian beban kendaraan secara merata (load balancing) ke berbagai alternatif ruas jalan. Hal ini yang menjadi motivasi untuk mengurangi masalah kemacetan di Kota Bandung. 


\section{Model Load Balancing dan Rancangan Simulasi}

\subsection{Teori Antrian}

Antrian adalah sebuah peristiwa dimana suatu entiti (misal: pelanggan) menunggu didalam suatu sistem untuk memperoleh layanan (service) [6,7]. Teori antrian merupakan bagian dari bidang ilmu Matematika yang berisi sistem antrian sebagai suatu himpunan entiti yang dilengkapi dengan suatu aturan yang mengatur kedatangan dan pelayanan. Terjadinya antrian terutama tergantung dari karakteristik kedatangan dan proses pelayanan. Penentu antrian lain yang penting adalah disiplin antrian yaitu aturan keputusan yang menjelaskan cara melayani pengantri, misalnya, yang pertama datang yang pertama dilayani, dan lain-lain. Jika tidak ada antrian berarti terdapat pelayan yang menganggur atau kelebihan fasilitas pelayanan.

Teori antrian banyak digunakan pada terapan berbagai bidang ilmu, diantaranya adalah untuk memodelkan sistem jaringan komputer atau internet [8, 9, 10], Request Routing [11], model transportasi [12], dan lain-lain. Dalam beberapa kasus, teori antrian digunakan sebagai media pengambilan keputusan sebagaimana penerapan metode Bayes $[13,14,15,16]$ atau metode artificial intelligent lainnya.

\subsection{Load Balancing}

Load balancing dapat didefinisikan sebagai penyeimbangan arus pergerakan entiti sedemikian sehingga sejumlah entiti tidak tertumpu kepada satu lokasi tertentu yang dapat menyebabkan terhambatnya arus. Load balancing juga dapat diartikan sebagai pengalihan arus kendaraan kepada beberapa jalur alternatif secara dinamis [17] untuk menghindari penumpukkan kendaraan pada satu lokasi. Load balancing diimplementasikan pada arus lalu lintas dimana arus kendaraan dialirkan ke berbagai ruas jalan dengan tujuan untuk menyeimbangkan beban secara merata. Melalui teknik load balancing diharapkan tidak penumpukkan kendaraan di satu titik yang menyebabkan kemacetan.

\subsection{Rancangan Simulasi}

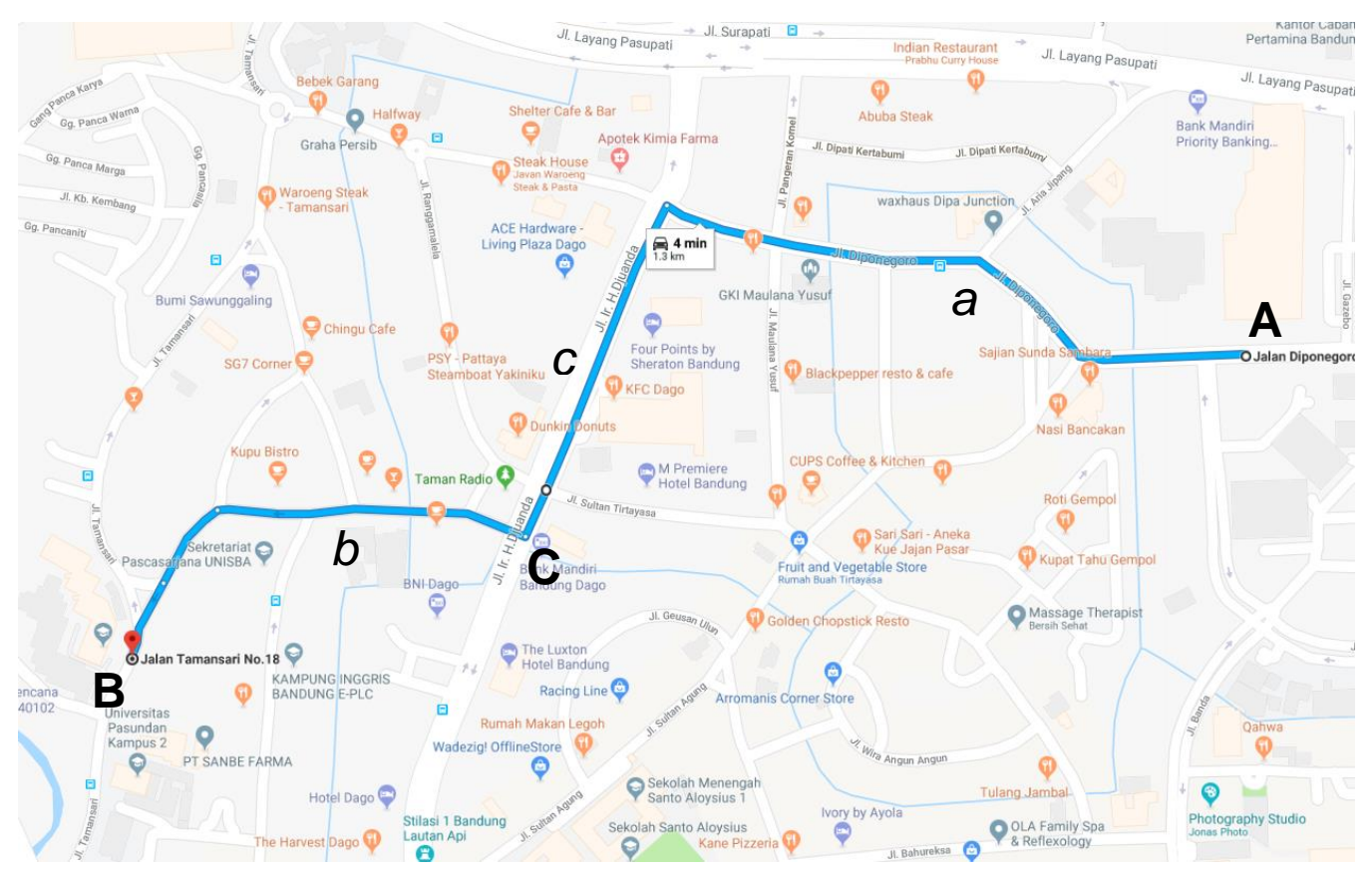

Gambar 1. Lokasi lalu lintas kota Bandung untuk simulasi Load Balancing 
Rancangan simulasi untuk Load Balancing disusun dengan menggunakan aplikasi SimEvents MATLAB [18]. Rancangan simulasi disusun berdasarkan pada salah satu area lokasi ruas jalan di Kota Bandung sebagaimana ditunjukkan pada Gambar 1.

Dengan demikian akan dilakukan eksperimen melalui simulasi dengan mengimplementasikan metode Load Balancing. Simulator manajemen lalu lintas dengan load balancing dibangun dengan menggunakan aplikasi SimEvents MATLAB, ditunjukkan pada Gambar 2. Dalam artikel ini, pembagian beban lalu lintas akan dilakukan dua jalur lainnya selain jalur utama.

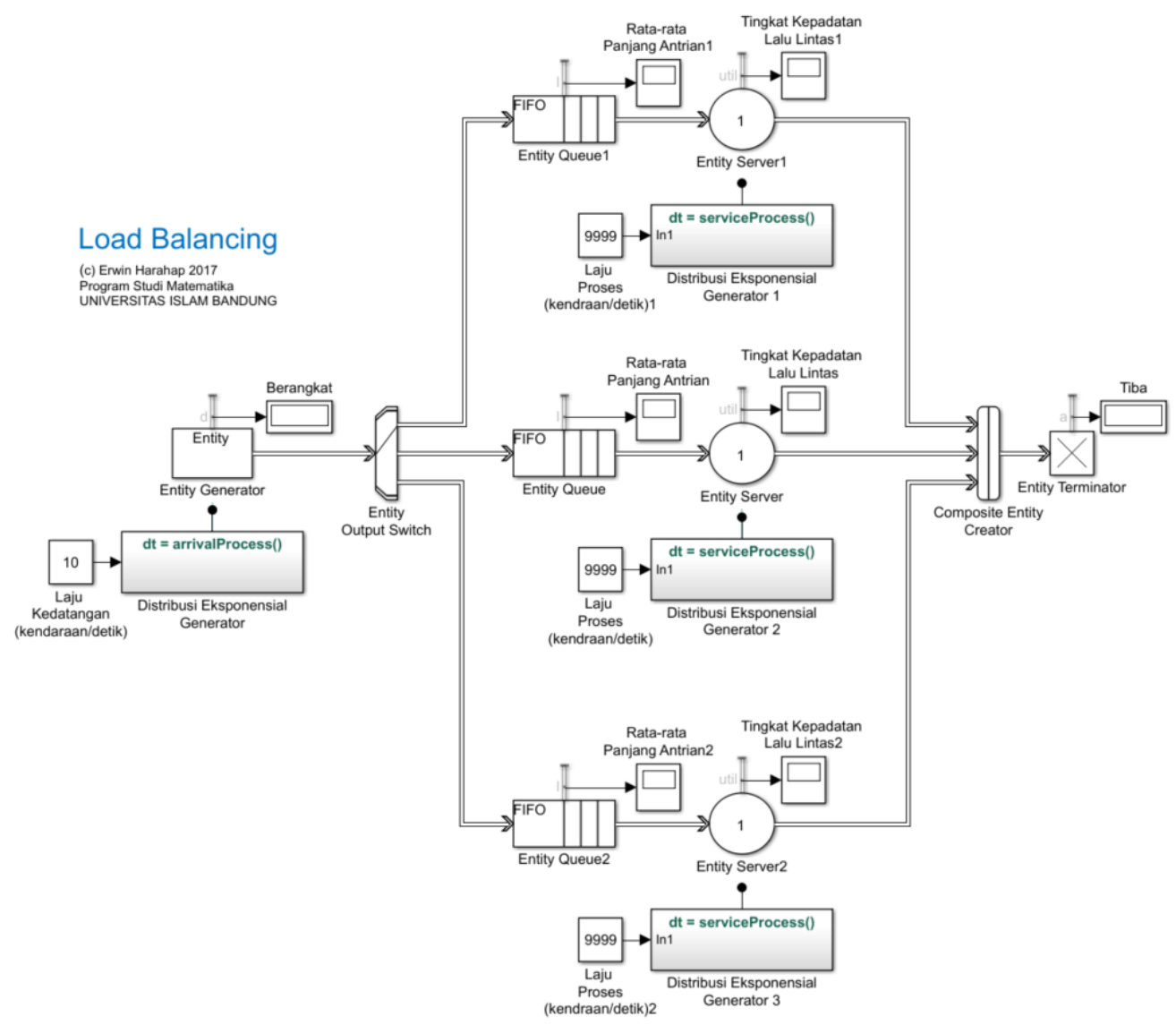

Gambar 2. Simulator manajemen lalu lintas dengan load balancing

\section{Hasil dan Pembahasan}

Metode Load Balancing kami usulkan sebagai salah satu alternatif untuk memecahkan permasalahan kemacetan lalu lintas. Simulasi dilaksanakan berdasarkan pada rancangan sistem sebagaimana ditunjukkan pada gambar 2. Kami asumsikan rata-rata kendaraan yang berangkat dari titik A ke titik B adalah 20 kendaraan per menit. Kepadatan lalu lintas di jalur $c$ adalah 19 kendaraan/menit. Simulasi dilaksanakan dalam dua tahap. Tahap pertama adalah perjalanan kendaraan melalui jalur utama tanpa implementasi load balancing. Tahap kedua adalah perjalanan dengan mengimplementasikan metode load balancing. Durasi waktu simulasi adalah selama 200 menit.

Gambar 3 menunjukkan hasil simulasi lalu lintas tanpa metode load balancing. Berdasarkan hasil simulasi, tingkat kepadatan lalu lintas menunjukkan pertumbuhan antrian dimulai dari 20 menit setelah simulasi dijalankan. Kepadatan lalu lintas terus meningkat hingga akhir simulasi. Peningkatan jumlah antrian kendaraan sejalan dengan lama waktu menunggu dalam antrian. Jumlah kendaraan dalam antrian fluktuatif dari 0 hingga 240 kendaraan dengan lama waktu menunggu maksimal selama 6 menit. 

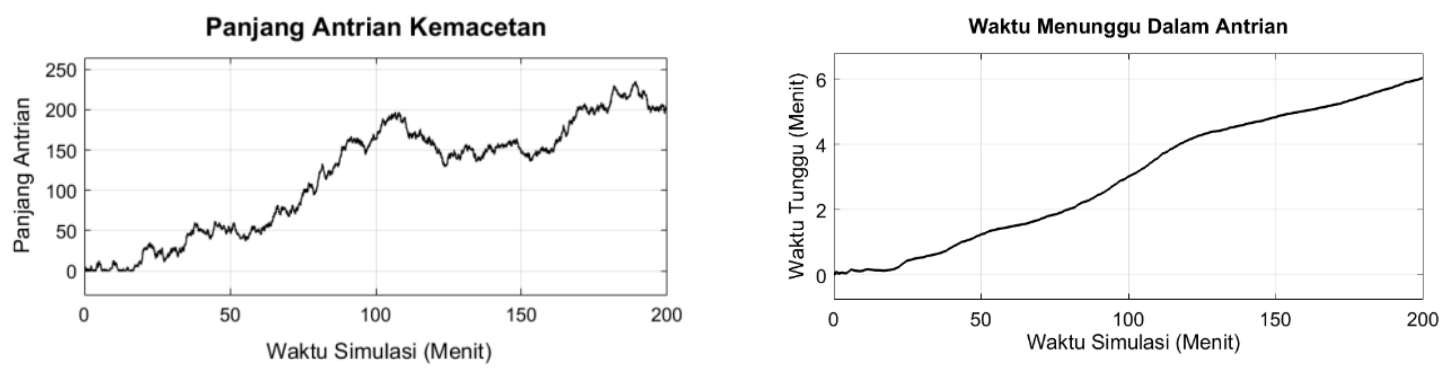

Gambar 3. Hasil simulasi lalu lintas tanpa implementasi Load Balancing

Simulasi selanjutnya akan dilakukan dengan menerapkan metode load balancing. Aliran kendaraan tidak hanya melalui pada jalur $c$ tetapi juga pada dua jalur lainnya. Kami asumsikan kedua jalur lain memiliki kepadatan yang sama dengan jalur $c$. Pada simulasi ini kami implementasikan dua jenis load balancing, yaitu Round Robin dan Random. Round Robin adalah jenis algoritma load balancing dengan membagi aliran tiap satuan kendaraan secara merata mengikuti urutan secara melingkar. Mulai dari alternatif jalur pertama, kedua, ketiga, dan kembali lagi ke jalur pertama. Random adalah jenis algoritma load balancing yang membagi aliran tiap satuan kendaraan secara acak, dalam hal ini, tiap-tiap kendaraan akan dibagi untuk menempuh ketiga alternatif jalur secara acak. Dalam kurun waktu yang relatif cukup lama, algoritma Random akan memiliki karakteristik yang sama dengan algoritma Round Robin.
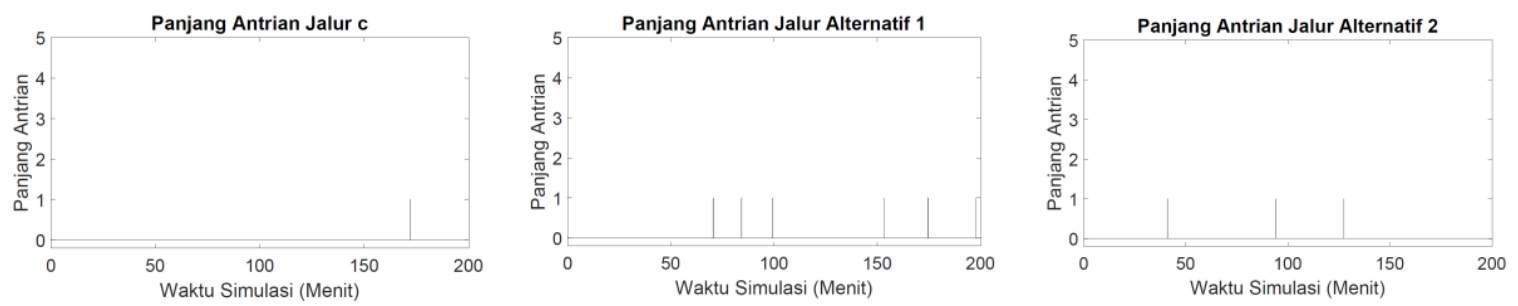

Gambar 4. Hasil simulasi lalu lintas dengan load balancing algoritma Round Robin

Gambar 4 menunjukkan hasil simulasi lalu lintas dengan menerapkan metode load balancing. Jenis algoritma load balancing yang diimplementasikan adalah Round Robin. Berdasarkan hasil simulasi, tingkat kepadatan lalu lintas menunjukkan sedikit sekali pertumbuhan antrian pada ketiga jalur. Hal ini disebabkan karena adanya pembagian kendaraan secara merata terhadap ketiga jalur dimana aliran kendaraan berada dibawah batas ambang kapasitas jalan sehingga tidak menimbulkan kemacetan.
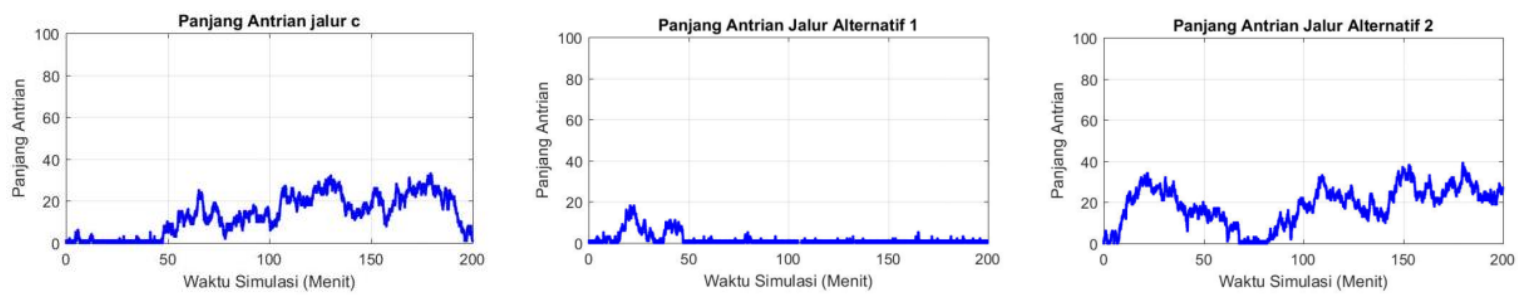

Gambar 5. Hasil simulasi lalu lintas dengan load balancing algoritma Random

Gambar 5 menunjukkan hasil simulasi lalu lintas dengan menggunakan metode load balancing jenis algoritma Random. Hasil simulasi menunjukkan tingkat kepadatan lalu lintas yang fluktuatif. Terdapat peningkatan antrian kendaraan di ketiga jalur, namun tidak setinggi pada saat metode load 
balancing tidak diterapkan. Berbeda dengan Round Robin dimana sebaran kendaraan betul-betul merata sehingga sama sekali tidak tampak antrian kendaraan, sebagaimana ditunjukkan pada Gambar 3.

\section{Kesimpulan}

Berdasarkan hasil dari simulasi, dapat disimpulkan bahwa metode load balancing memberikan solusi yang cukup signifikan dalam mengurangi panjang antrian lalu lintas. Antrian lalu lintas berkurang menunjukkan bahwa kemacetan lalu lintas dapat dihindari, sehingga waktu perjalanan dari satu tempat ke tempat lain dapat ditempuh secara normal. Semoga metode ini dapat dijadikan sebagai metode alternatif dalam mengurangi kemacetan lalu lintas.

Sebagai saran untuk penelitian lebih lanjut, perlu dikembangkan mengenai alternatif jalur disamping jalur utama yang selama ini dipergunakan, khususnya oleh warga Bandung, mengenai kualitas jalan sehingga layak untuk digunakan sebagai jalur alternatif. Juga dapat diterapkan jenis algoritma lainnya dari metode load balancing untuk memperoleh hasil yang lebih baik dari algoritma Round Robin dan Random.

\section{Referensi}

[1] "Mengurai Masalah Kemacetan Kota Bandung," 26 Oktober 2011. [Online]. Available: http://infobandung.co.id/. [Accessed 3 Juni 2017].

[2] "Pembatasan Kendaraan, Efektifkah atasi kemacetan?", Agustus 2011. [Online]. Available: http://ylki.or.id. [Accessed 26 Februari 2017].

[3] Rakyat Merdeka Online, "Atasi Kemacetan, Pemerintah Harus Berani Batasi Kendaraan," Kantor Berita Politik RMOL.co, 22 September 2016. [Online]. Available: http://rmol.co. [Accessed 15 April 2017].

[4] S. Pembaruan, "Pengguna Jalan Biang Kemacetan," 24 Oktober 2010. [Online]. Available: http://sp.beritasatu.com. [Accessed 27 Februari 2017].

[5] E. A. Retaduari, "Ini Aneka Penyebab Macet Parah di Jakarta Senin Pagi Ini," Detik News, 12 Juni 2017. [Online]. Available: https://news.detik.com. [Accessed 16 Mei 2017].

[6] Gunter Bolch, Stefan Greiner, Hermann de Meer, Kishor S. Trivedi, Queueing Networks and Markov Chains 2nd, New Jersey, USA.: John Wiley \& Sons, Inc., 2006.

[7] Ng Chee-Hock, Soong Boon-Hee, Queueing Modelling Fundamentals 2nd, Sussex, England.: John Wiley \& Sons Ltd., 2008.

[8] E. Harahap, I. Sukarsih, G. Gunawan, M. Y. Fajar, D. Darmawan and H. Nishi, "A Model-Based Simulator for Content Delivery Network using SimEvents MATLAB-Simulink," INSIST: International Series on Interdisciplinary Science and Technology, vol. 1, no. 1, pp. 30-33, 2016.

[9] E. Harahap, J. Wijekoon, R. Tennekoon, F. Yamaguchi, S. Ishida and H. Nishi, "Modeling of Router-based Request Redirection for Content Distribution Network," International Journal of Computer Applications (IJCA), vol. 76, no. 13, pp. 37-46, 2013.

[10] E. Harahap, A. A. Nurrahman and D. Darmawan, "A Modeling Approach for Event-Based Networking Design Using MATLAB-SimEvents," in International Multidisciplinary Conference (IMC) 2016, Jakarta, Indonesia, 2016.

[11] E. Harahap, J. Wijekoon, R. Tennekoon, F. Yamaguchi and H. Nishi, "Router-based request redirection management for a next-generation content distribution network," in GLOBECOM Workshops, 2013 IEEE, Atlanta, USA., 2013.

[12] E. Harahap, F. H. Badruzzaman and M. Y. Fajar, "Model dan Simulasi Sistem Transportasi Dengan Teori Antrian," Matematika - Jurnal Teori dan Terapan Matematika, vol. 15, no. 1, 2016.

[13] E. Harahap, W. Sakamoto and H. Nishi, "Failure prediction method for network management system by using Bayesian network and shared database," in Information and Telecommunication Technologies (APSITT), 2010 8th Asia-Pacific Symposium on, Kota Kinabalu, Kucing, Malaysia., 2010.

[14] E. Harahap, J. Wijekoon, R. Tennekoon, F. Yamaguchi, S. Ishida and H. Nishi, "A router-based management system for prediction of network congestion," in Advanced Motion Control (AMC), 2014 IEEE 13th International Workshop on, Yokohama, Japan., 2014.

[15] E. Harahap, "Prediksi Kemacetan pada Jaringan Komputer Menggunakan Metode Naive Bayesian Classifier," STATISTIKA: Journal of Theoretical Statistics and Its Applications, vol. 12, no. 1, 2012. 
[16] E. Harahap, J. Wijekoon, R. Tennekoon, F. Yamaguchi, S. Ishida and H. Nishi, "Distributed algorithm for router-based management of replica server in next-CDN infrastructure," in Cyber-Enabled Distributed Computing and Knowledge Discovery (CyberC), 2013 International Conference on, Beijing, China., 2013.

[17] E. Harahap, I. Sukarsih, H. Farid and M. Y. Fajar, "Model Antrian Dengan Pengalihan Dinamis untuk Mengurangi Kemacetan Jalan Raya," ETHOS (Jurnal Penelitian dan Pengabdian), vol. 5, no. 2, pp. 182-185, 2017.

[18] "SimEvents: Model and simulate discrete-event systems," MathWorks, 2017. [Online]. Available: https://www.mathworks.com/products/simevents.html. [Accessed 16 Juli 2017]. 